\title{
The need for communication between clinicians and pathologists in the context of oral and maxillofacial diseases
}

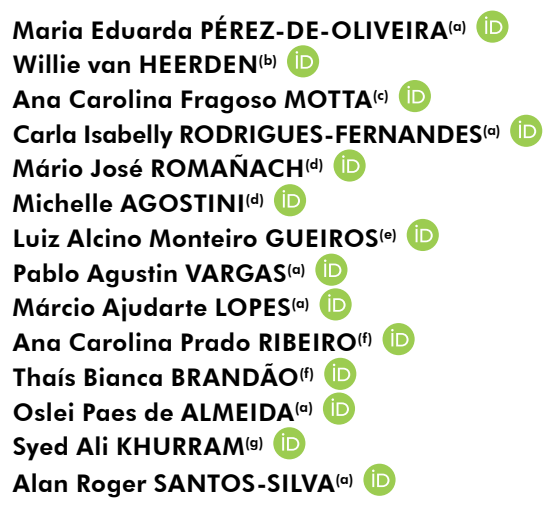

(a) Universidade Estadual de Campinas - Unicamp, Piracicaba Dental School, Department of Oral Diagnosis, Oral Pathology and Semiology Areas, Piracicaba, SP, Brazil.

(b) University of Pretoria, School of Dentistry, Department of Oral Pathology and Oral Biology, Pretoria, South Africa.

(c) Universidade de São Paulo - USP, School of Dentistry of Ribeirão Preto, Department of Stomatology, Public Health and Forensic Dentistry, Ribeirão Preto, SP, Brazil.

(d) Universidade Federal do Rio de Janeiro - UFRJ, School of Dentistry, Department of Oral Diagnosis and Pathology, Rio de Janeiro, RJ, Brazil.

(e) Universidade Federal de Pernambuco - UFPE, School of Dentistry, Department of Clinic and Preventive Dentistry, Oral Medicine Unit, Recife, PE, Brazil.

(f) Instituto do Câncer do Estado de São Paulo - ICESP, Dental Oncology Service, São Paulo, SP, Brazil.

(g) University of Sheffield, School of Clinical Dentistry, Unit of Oral and Maxillofacial Pathology, Sheffield, UK.

Declaration of Interests: The authors certify that they have no commercial or associative interest that represents a conflict of interest in connection with the manuscript.

\section{Corresponding Author:}

Maria Eduarda Pérez-de-Oliveira

E-mail: meduardaperezo@gmail.com

https://doi.org/10.1590/1807-3107bor-2022.vol36.0008

Submitted: February 2, 2021

Accepted for publication: June 2, 2021

Last revision: September 14, 2021
Abstract: Good communication between clinicians and pathologists is a vital element in the diagnostic process, and poor communication can adversely affect patient care. There is a lack of research about communication in diagnostic oral and maxillofacial pathology. This narrative review explores different aspects of the quality of communication between clinicians and oral pathologists, with a focus on the diagnosis of oral and maxillofacial diseases. An electronic search was carried out in MEDLINE through the PubMed, Scopus, and Embase databases up to April 2021. No studies reporting communication, its adequacy or the required skills between clinicians and pathologists in oral diagnosis were found. According to studies published in medicine, strategies for improving communication skills include clinicianpathologist collaboration; a well-formatted, clear and thorough report; training in communication skills; and patient-centered care. Further studies evaluating the current practices and quality in oral and maxillofacial pathology are required to identify barriers and encourage optimal communication to facilitate diagnosis, as well as patient safety.

Keywords: Communication; Pathologists; Diagnosis, Oral; Pathology, Oral.

\section{Introduction}

Histopathological diagnosis is a complex, systematic and collaborative process, which involves pathological reasoning and information gathering to determine the cause of diseases and potential prognosis. Communication is an essential tool in the process of diagnosing oral diseases, which relies on clinical as well as histopathological analysis. Poor communication between clinicians and pathologists may have potential implications for the patient's physical and mental health. Communication skills are not easy to define or teach, however, and there are no clear guidelines about what is adequate, especially in the context of oral and maxillofacial (OMF) diseases. ${ }^{1}$

Dialogue between clinicians and pathologists is an indispensable approach to reaching the correct histopathological diagnosis. It is necessary not only for the benefit of the professionals but also to improve patient 
care by avoiding harm, unnecessary treatment and distress. ${ }^{2}$ When the relationship between pathologist and clinician is one of openness, mutual trust and respect, there are fewer mistakes, and medical, legal, and economic damages are avoided. ${ }^{3}$

The role of communication has been superficially explored in the medical field, ${ }^{1,2,4,5}$ however, in the diagnosis of OMF pathologies has not been reported to date. We thus undertook a narrative review of communication skills in OMF pathology. This review explores critical factors related to communication requirements between clinicians and pathologists, with a focus on OMF diagnosis, and suggests different aspects that could improve this practice, and consequently achieve optimal patient care.

\section{Methodology}

An electronic search was carried out in MEDLINE through the PubMed, Scopus, and Embase databases using the following keywords: communication, interpersonal skills, diagnosis, reporting, oral, maxillofacial, pathologist, surgeon, physician, and clinician. Articles that discussed communication between clinicians and pathologists in the diagnostic process and were published in the English-language literature until April 2021 were reviewed. The gathered data was divided into five thematic sections: a) clinician-pathologist collaboration, b) pathology report format and style, c) exploring other methods of communication, d) communication skills training, and e) patient-centered care.

\section{Results}

No studies reporting communication, its adequacy or required skills between clinicians and pathologists in oral diagnosis were found. To the best of our knowledge, this is the first study to address the communication guidelines between clinicians and pathologists in the field of OMF pathology. The following discussion was thus based on studies published in medicine and their possible application to OMF diagnosis (Table). This narrative review does not intend to present standard protocols of communication and/or adequate skills, but to foment a discussion that may improve this collaboration.

\section{Discussion}

\section{Clinician-pathologist collaboration}

The clinician-pathologist collaboration is summarized in a schematic illustration (Figure 1). Pathologists often depend on clinical information to provide accurate diagnosis. ${ }^{6}$ It is therefore pertinent that pathology request forms are completed appropriately and thoroughly. Inadequate or absent clinical information not only impairs the pathological analysis but can also lead to diagnostic errors and a more descriptive (and non-definitive) report., ${ }^{2,7}$ The College of American Pathologists has reported that $2.4 \%$ of samples submitted to pathology laboratories have no clinical information provided by clinicians ${ }^{6}$. Indeed, $10 \%$ of the amended pathology reports resulted from cases that had additional information provided after the original report. ${ }^{8}$

Clinicians must provide clinical photographs and imaging exams. For example, leukoplakia, which is the most common potentially malignant disorder, may clinically present as white, mixed or even red lesions, which are called erythroleukoplakia. The clinical color, as well as site, size, texture, duration and smoking/alcohol history, is important information for a definitive diagnosis, and also for a risk assessment of the progression to oral cancer ${ }^{9}$. In these cases, it is also essential to rule out other similar conditions, such as benign alveolar ridge keratosis and morsicatio buccarum, which require different management. ${ }^{10}$ Another critical condition is oral lichenoid lesions, including lichenoid drug reactions and lichenoid lesions of graft-versus-host disease. Clinically and histologically these lesions may be indistinguishable from oral lichen planus. A careful clinicopathological correlation for the definitive diagnosis of oral lichen planus is then essential. ${ }^{11}$

With regard to bone pathologies, it is well known that benign fibro-osseous lesions (FOL) of the jaw show overlapping microscopic features requiring radiological and clinical correlation to establish the correct diagnosis. This distinction is particularly 
Table. Key features of studies concerning communication skills in the diagnostic process.

\begin{tabular}{|c|c|c|c|c|}
\hline Author (year) & Country & Type of study & Objective & Key features \\
\hline $\begin{array}{l}\text { Lehr and Bosman' } \\
\text { (2016) }\end{array}$ & $\begin{array}{l}\text { Germany } \\
\text { and } \\
\text { Switzerland }\end{array}$ & Review article & $\begin{array}{l}\text { To explore important aspects of } \\
\text { communication in pathology. }\end{array}$ & $\begin{array}{l}\text { The relevance of clinical information; routine second } \\
\text { opinion; conclusive final diagnosis; communication } \\
\text { of unexpected findings and technical problems. }\end{array}$ \\
\hline Suleiman $^{2}$ (2015) & Nigeria & Review article & $\begin{array}{l}\text { To discuss pathologist-clinician } \\
\text { collaboration for improving the } \\
\text { quality of patient care. }\end{array}$ & $\begin{array}{l}\text { The importance of clinical information; } \\
\text { exploring other means of communication; use } \\
\text { of accurate phrases to describe pathology } \\
\text { reports; multidisciplinary teams to improve the } \\
\text { communication. }\end{array}$ \\
\hline $\begin{array}{l}\text { Powsner et al. }{ }^{4} \\
(2000)\end{array}$ & $\begin{array}{l}\text { United } \\
\text { States }\end{array}$ & Cross-sectional & $\begin{array}{l}\text { To compare clinician } \\
\text { comprehension of pathologist } \\
\text { intent in pathology reports. }\end{array}$ & $\begin{array}{l}\text { There is a communication gap between pathologists } \\
\text { and surgeons. Familiarity with report formats and } \\
\text { clinical experience help reduce this gap. }\end{array}$ \\
\hline $\operatorname{Nakhleh}^{5}(2011)$ & $\begin{array}{l}\text { United } \\
\text { States }\end{array}$ & Review article & $\begin{array}{c}\text { To discuss different aspects of } \\
\text { pathology practice that represent } \\
\text { quality communication in surgical } \\
\text { pathology. }\end{array}$ & $\begin{array}{l}\text { Physician satisfaction with pathology department; } \\
\text { pathology report content and completeness; } \\
\text { pathology report and style; intraoperative } \\
\text { consultation; urgent and unexpected diagnosis; } \\
\text { exploring other methods of communication. }\end{array}$ \\
\hline $\begin{array}{l}\text { Nakhleh et al. }{ }^{6} \\
\text { (1999) }\end{array}$ & $\begin{array}{l}\text { United } \\
\text { States }\end{array}$ & Cross-sectional & $\begin{array}{l}\text { To examine the frequency and } \\
\text { nature of problems caused by } \\
\text { inadequate clinical data. }\end{array}$ & $\begin{array}{l}\text { Inadequate clinical information may produce } \\
\text { diagnostic errors. }\end{array}$ \\
\hline Nutt et al. ${ }^{7}(2008)$ & $\begin{array}{l}\text { South } \\
\text { Africa }\end{array}$ & Cross-sectional & $\begin{array}{l}\text { To evaluate the extent and impact } \\
\text { of incomplete laboratory request } \\
\text { forms. }\end{array}$ & $\begin{array}{l}\text { Incorrect or incomplete data provided to the } \\
\text { laboratory could significantly affect the success and } \\
\text { cost of overall treatment. }\end{array}$ \\
\hline $\begin{array}{l}\text { Nakhleh and } \\
\text { Zarbo }^{8} \text { (1998) }\end{array}$ & $\begin{array}{l}\text { United } \\
\text { States }\end{array}$ & Cross-sectional & $\begin{array}{l}\text { To evaluate amended report rates, } \\
\text { and practices that lower amended } \\
\text { report rates. }\end{array}$ & $\begin{array}{l}\text { There is an association between lower amended } \\
\text { report rates and diagnostic slide reviews of cases } \\
\text { prior to completion of the pathology report. }\end{array}$ \\
\hline $\begin{array}{l}\text { Attanoos et al. }{ }^{15} \\
\text { (1996) }\end{array}$ & $\begin{array}{l}\text { United } \\
\text { Kingdom }\end{array}$ & Cross-sectional & $\begin{array}{l}\text { To compare the interpretation } \\
\text { among pathologists and surgeons } \\
\text { of descriptive phrases used in } \\
\text { pathology reports. }\end{array}$ & $\begin{array}{l}\text { The adoption of a limited number of descriptive } \\
\text { phrases that are mutually understood and acceptable } \\
\text { for use by both pathologists and clinicians is } \\
\text { recommended to avoid misinterpretations. }\end{array}$ \\
\hline $\begin{array}{l}\text { Atchyuta et al. }{ }^{16} \\
(2018)\end{array}$ & India & Cross-sectional & $\begin{array}{l}\text { To make a comparative assessment } \\
\text { of the interpretation and use of } \\
\text { common descriptive phrases found } \\
\text { in pathology reports between } \\
\text { clinicians and pathologists. }\end{array}$ & $\begin{array}{l}\text { The adoption of a limited number of descriptive } \\
\text { phrases that are mutually understood and acceptable } \\
\text { for use by both pathologists and clinicians is } \\
\text { recommended to avoid miscommunication in } \\
\text { pathology reports. }\end{array}$ \\
\hline $\begin{array}{l}\text { Manion et al. }{ }^{19} \\
\text { (2008) }\end{array}$ & $\begin{array}{l}\text { United } \\
\text { States }\end{array}$ & Cross-sectional & $\begin{array}{l}\text { To determine the clinical } \\
\text { consequences of second opinion } \\
\text { reviews of referral material, } \\
\text { specifically in cases of major } \\
\text { diagnostic disagreement. }\end{array}$ & $\begin{array}{l}\text { Mandatory second opinion is an important part of } \\
\text { patient care in the referral setting. }\end{array}$ \\
\hline $\begin{array}{l}\text { Lindley et al. }{ }^{21} \\
(2014)\end{array}$ & $\begin{array}{l}\text { United } \\
\text { States }\end{array}$ & Cross-sectional & $\begin{array}{l}\text { To assess the setting, varieties, } \\
\text { and frequency of use of phrases of } \\
\text { diagnostic uncertainty in pathology } \\
\text { reports and how these phrases } \\
\text { are interpreted by clinicians and } \\
\text { pathologists }\end{array}$ & $\begin{array}{l}\text { Non-standardized language used in the } \\
\text { communication of diagnostic uncertainty is a source } \\
\text { of miscommunication. }\end{array}$ \\
\hline $\begin{array}{l}\text { Galloway and } \\
\text { Taiyeb }^{22}(2011)\end{array}$ & $\begin{array}{l}\text { United } \\
\text { Kingdom }\end{array}$ & Cross-sectional & $\begin{array}{l}\text { To analyze the wide range of } \\
\text { interpretation of uncertainty terms } \\
\text { used in pathology reports }\end{array}$ & $\begin{array}{l}\text { Uncertainty phrases used in pathology reports } \\
\text { produce wide variations in interpretation. }\end{array}$ \\
\hline $\begin{array}{l}\text { Bracamonte et al. }{ }^{24} \\
(2016)\end{array}$ & $\begin{array}{l}\text { United } \\
\text { States }\end{array}$ & Cross-sectional & $\begin{array}{c}\text { To analyze perceptions of } \\
\text { uncertainty phrases in pathology } \\
\text { report }\end{array}$ & $\begin{array}{l}\text { The use of uncertainty expressions produces multiple } \\
\text { perceptions of final diagnosis. }\end{array}$ \\
\hline $\begin{array}{l}\text { Valenstein }{ }^{25} \\
\text { (2008) }\end{array}$ & $\begin{array}{l}\text { United } \\
\text { States }\end{array}$ & Review article & $\begin{array}{l}\text { To provide guidance to report } \\
\text { designers and authors in how to } \\
\text { format reports to maximize the } \\
\text { fidelity of information. }\end{array}$ & $\begin{array}{c}\text { The use of diagnostic headlines, maintenance of } \\
\text { layout continuity, optimization of information density, } \\
\text { and reduction of extraneous information optimize } \\
\text { communication. }\end{array}$ \\
\hline $\begin{array}{l}\text { Branston et al. }{ }^{26} \\
(2002)\end{array}$ & $\begin{array}{l}\text { United } \\
\text { Kingdom }\end{array}$ & $\begin{array}{l}\text { Randomized } \\
\text { controlled trial }\end{array}$ & $\begin{array}{l}\text { To determine whether reporting } \\
\text { guidelines and computerized } \\
\text { forms improve the completeness of } \\
\text { histopathology reporting. }\end{array}$ & $\begin{array}{l}\text { Guidelines and computerized forms significantly } \\
\text { improve the quality of histopathology reporting. }\end{array}$ \\
\hline
\end{tabular}


critical since FOL are tumors as well as reactive and developmental conditions, with variations in behavior and different treatment approaches. ${ }^{12}$ Another critical issue is the clinicopathological correlation of metastatic lesions to the OMF region. Due to their rarity at this site, metastatic tumors can be a diagnostic challenge, in both a clinical and histopathological context. In these cases, a histopathological evaluation is essential to determine the lineage of the tumor cells, however the medical history and a known primary tumor are extremely helpful in this process. ${ }^{13}$ Figures 2 and 3 illustrate examples of the importance of clinicopathological correlation in the OMF diagnostic process.

Adequate accompanying clinical information also has significant implications for a laboratory's financial budget. For example, when pathologists are faced with a suspicious malignant or metastatic lesion without the detailed clinical data, additional and somewhat extensive histochemical, immunohistochemical, and molecular analyses need to be undertaken to reach the final diagnosis, which also causes a delay in diagnosis and the commencement of treatment. ${ }^{1,14}$ Information concerning an underlying disease, immunosuppression, or primary tumor thus supports pathologists in performing additional stains. ${ }^{1}$ Clinicians should not hesitate to ask for explanations from OMF pathologists about any doubtful diagnoses or an unknown pathological entity. ${ }^{2}$

It is important to emphasize that improving collaboration does not rely exclusively on clinicians. Pathologists must also be aware of the clinician's expectations, providing a precise and timely diagnosis and a clear report. Although clinical information is essential, pathologists should recognize that it may lead to some bias in the diagnostic process. The pathologist should therefore initially look at the slides, formulate a putative diagnosis and then assess all available clinical data ${ }^{1}$. The diagnosis must be concise, clear and without any ambiguity to avoid misinterpretation by clinicians. ${ }^{15}$ The adoption of a limited number of descriptive phrases is better understood, acceptable for use and reduces distortions. ${ }^{16,17}$ It is also recommended

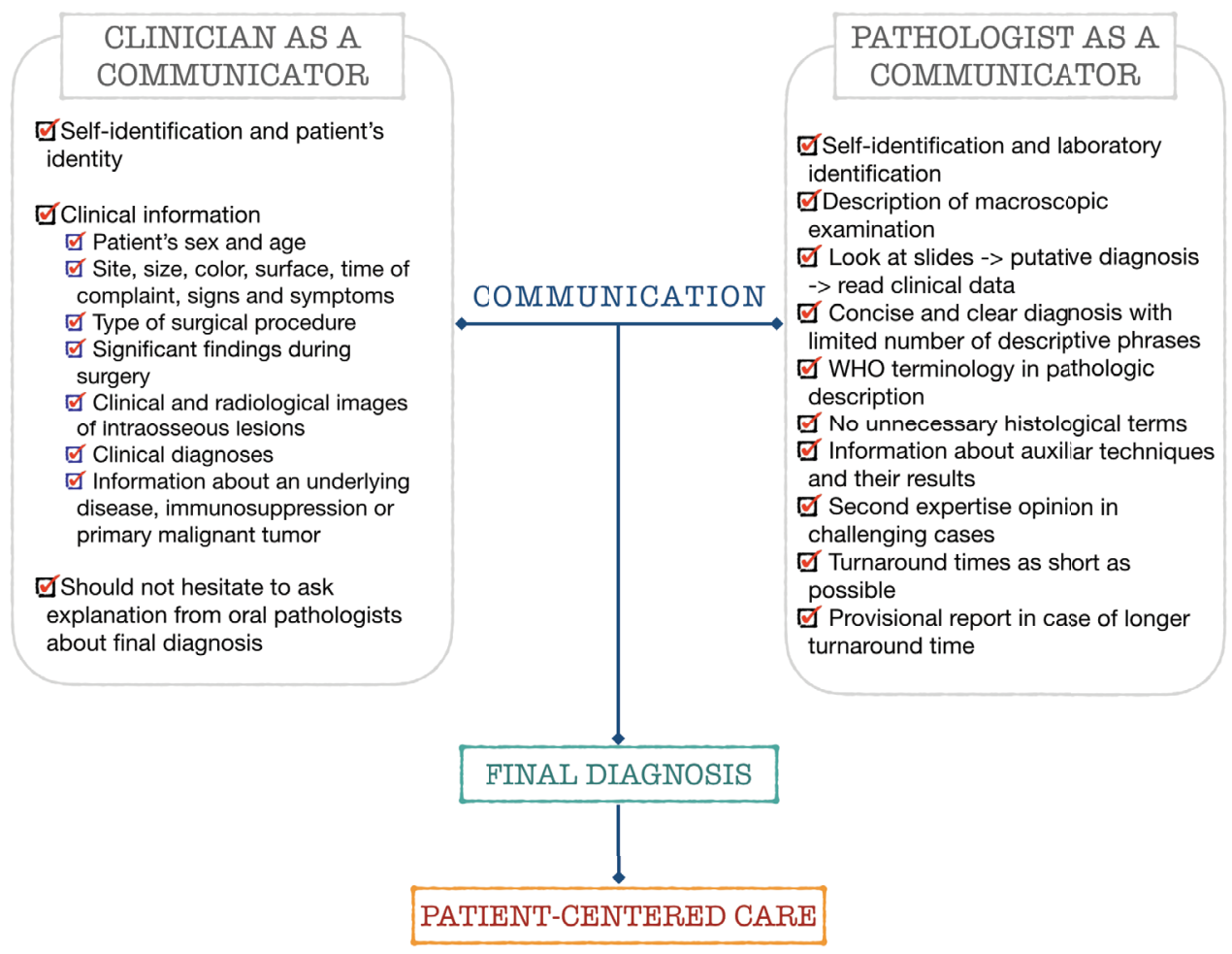

Figure 1. Schematic illustration of core clinician-pathologist communication in oral and maxillofacial pathology. 
that pathologists use World Health Organization (WHO) terminologies to describe pathology entities to ensure consistency. When auxiliary techniques, either histochemical, immunohistochemical stains or molecular studies, are performed, the results should be stated in the report and their meaning should be clearly described..$^{18,19}$ Challenging cases eventually may need double reporting by a local pathologist, or a second opinion from an external pathologist. This practice directly affects patient care, since discordant views may lead to an internal discussion to obtain a consensus, which must involve the clinician. ${ }^{20}$

It is presumed that the histopathological report is often the final line of diagnosis. When a diagnostic report expresses uncertainty expressions, such as "suggestive of", "consistent with", "favor", "in keeping with" or "suspicious of", clinicians and other pathologists can interpret these phrases in different ways, depending upon their understanding. This may result in misinterpretation and miscommunication with the patient. ${ }^{21,22}$ It may also cause delays in treatment, repeat biopsy or even a wrong intervention that may negatively affect a patient's health. Conversely, these descriptors are used to reflect the level of uncertainty found in surgical specimens received, or even to reduce the legal risk related to misdiagnosis.. ${ }^{22}$ Lindley et al. ${ }^{21}$ analyzed the gap between the pathologist's intention and clinician's perception, and noted a wide variation in interpreting these uncertainty expressions. The authors suggested that using non-standardized language to express diagnosis uncertainty can produce miscommunication. ${ }^{21,23}$
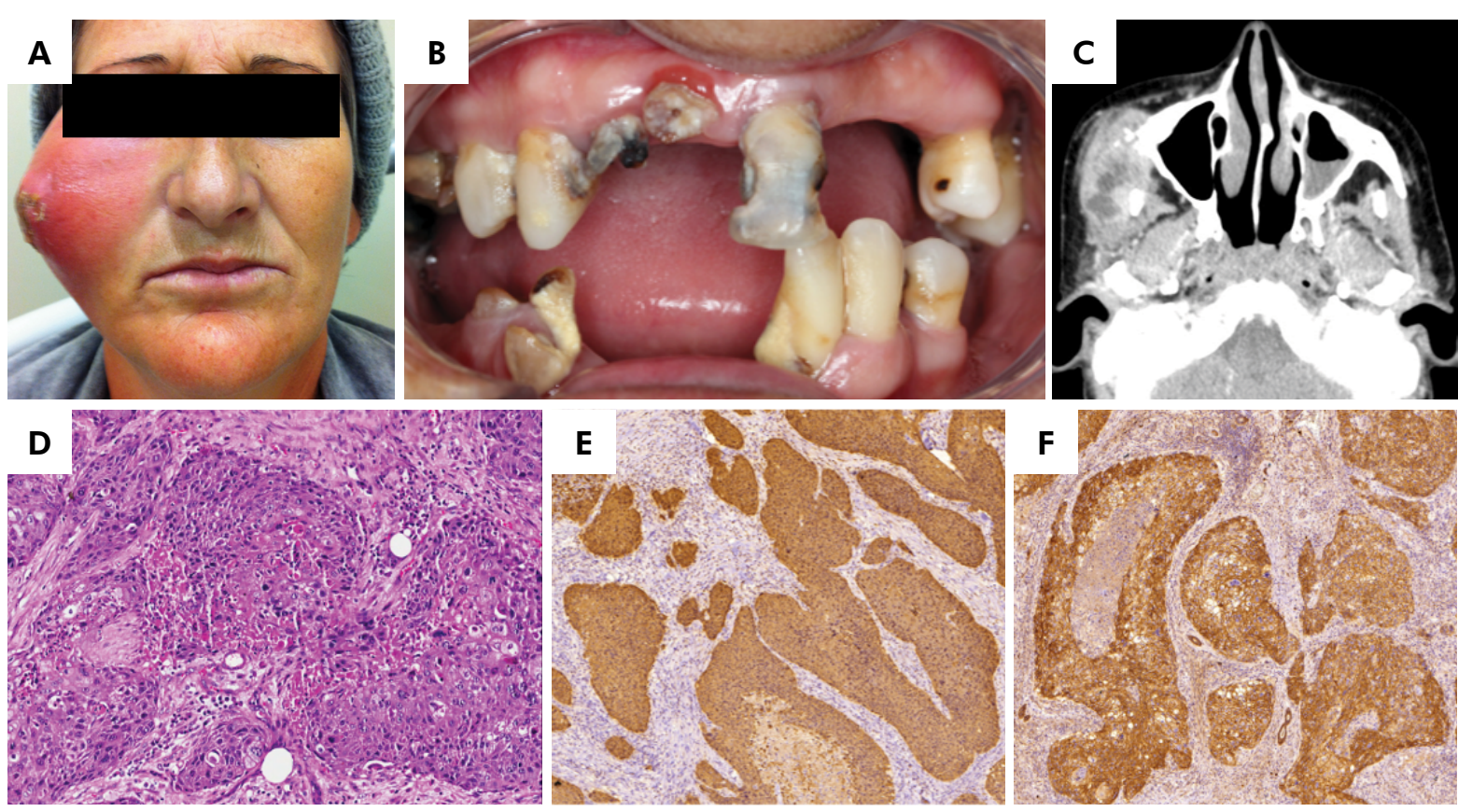

Figure 2. Clinicopathological aspects of metastatic breast carcinoma affecting the zygomatic bone. The history of a recent radical mastectomy due to invasive ductal carcinoma of the left breast was essential in the diagnostic process. 2A. A 38-year-old female patient was referred for evaluation of a "dental abscess", presenting facial swelling with an ulcerated and reddish covering skin in the right zygomatic region. During palpation, it was possible to observe a purulent drainage coming out of the lesion throughout the skin. 2B. Intraoral examination revealed periodontal disease, caries and residual roots. 2C. Computed tomography scan revealed a hyperdense lesion with hypodense areas (suggestive of necrosis) affecting the right zygomatic bone and infiltrating the left masseter muscle (axial section, soft tissue window). 2D. Based on the previous medical history of the patient, the diagnostic hypothesis was metastatic breast carcinoma. Incisional biopsy demonstrated islands of atypical squamous cell proliferation (hematoxylin-eosin, 200x). 2E. Further immunohistochemical analysis showed positivity for AE1/AE3 (immunohistochemistry, 50x) and 2F. EGFR (immunohistochemistry, 50x). The tumor cells were negative for Cerb-b2, estrogen and progesterone. This immunoprofile was similar to the primary breast tumor. A diagnosis of metastatic breast carcinoma was thus rendered. 

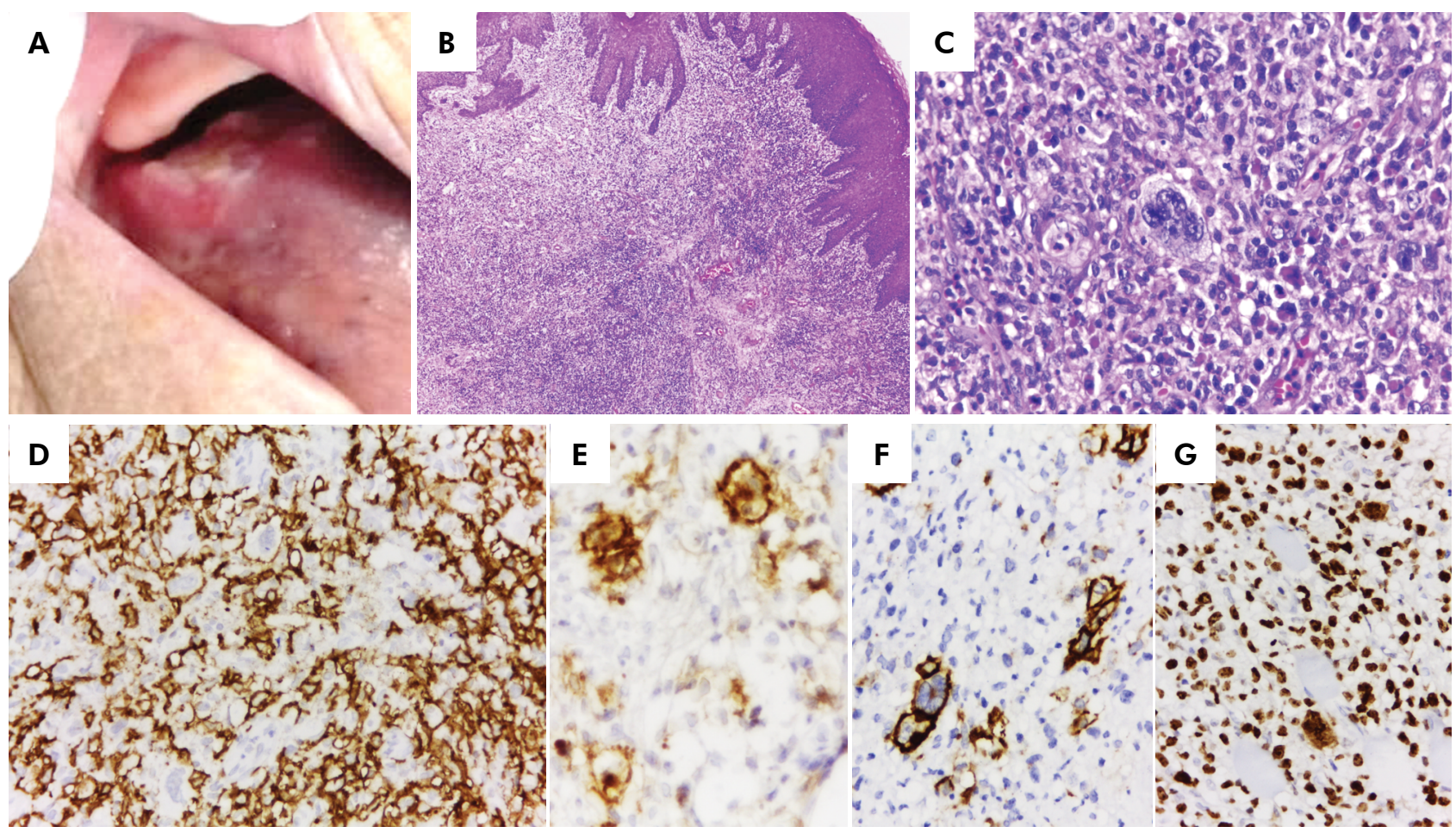

Figure 3. The communication between clinician and pathologist contributing to the diagnosis of an EBV-positive mucocutaneous ulcer. 3A. The lesion was an extremely painful ulcer on the posterior dorsum of the tongue of an 89-year-old female, who was submitted for an incisional biopsy. 3B. Microscopically, pseudoepitheliomatous hyperplasia of the intact epithelium adjacent to the ulcer was observed, covering the connective tissue, containing a dense proliferation of polymorphic infiltrate with angioinvasion and necrosis (hematoxylin-eosin, 100x). 3C. There was a variable number of plasma cells, histiocytes, eosinophils, and some ReedSternberg-like cells (hematoxylin-eosin, 400x). Under suspicion of a large B cell lymphoma, the patient was immediately referred to the hematology service for initial investigation during immunohistochemical reactions. The clinical check-up ruled out systemic disease and nutritional support was offered for the patient. 3D. The immunohistochemical analysis revealed strongly positivity for CD20 (immunohistochemistry, 100x), while Hodgkin-like cells were positive for 3E. CD30 (immunohistochemistry, 400x) and 3F. LMP-1 (immunohistochemistry, 400x). 3G. The Ki-67 proliferative index was 90\% (immunohistochemistry, 100x). Two weeks after the incisional biopsy the clinician observed a significant reduction in size of the oral ulcer, and improvement of overall health status of the patient, which contributed to establishing a diagnosis through clinicopathologic correlation. The patient underwent continuous follow-up until the complete healing of the ulcer two months later.

To avoid this, clinicians should be aware of limits and dilemmas from a pathology point of view, and whenever possible include a note to try to explain these expressions of uncertainty. However, additional studies are required to evaluate the precise impact of uncertainty as a result of pathology-related expressions on patient care, to identify the magnitude of this problem and overcome these challenges.

\section{Pathology report format and style}

The most critical component of a pathologist's communication in the diagnostic process is the pathology report content. It is the official version and the materialization of the clinician and pathologist interactions. It is therefore fundamental that reports are well-formatted and thorough. There are published guidelines for reporting formats and styles. ${ }^{18,24}$ There are indications that electronic reports are better than free-text reports, due to ease of formatting and a more uniform and consistent layout, as well as easier access for clinicians, pathologists, and anyone else involved in a patient's care ${ }^{5,25,26}$. Branston et al. ${ }^{25}$ suggest that guidelines and computerized report forms/templates improve the quality of histopathological reporting. Valenstein ${ }^{24}$ provided guidelines for formatting reports in pathology, and considered the following four principles: a) headlines to emphasize key points, 
b) maintenance of layout continuity, c) optimization of information density, and d) reduction of clutter.

Headlines emphasize the most critical element of the pathological report, which is the final diagnosis. If the diagnosis is not headlined, reports become "specimen-centered" because the components are referred to as specimens and diagnosis with equal emphasis. In contrast, the use of headlines works to create a "patient-centered report", which separates the critical element (diagnosis) from other information about the surgical specimen. ${ }^{5,24}$

Continuity of layout helps clinicians to complete the required information in a more uniform way. Using a consistent layout for reports means the reader can glean the patient's identity and final diagnosis more easily and quickly. To optimize information density in a histopathological report, elements must be placed in "familiar groups" and in a logical sequence for easier comprehension, including a patient identity section, macroscopic examination section, auxiliary techniques section, and final diagnosis section. Finally, to reduce clutter, the report should not include unnecessary information. Additional, ambiguous and less known histological terms with no clinical or prognostic relevance should be avoided. Nonessential information competes with the main data, and pathologists must ensure that the report is transmitting the final diagnosis to the reader in an optimal way. ${ }^{5,24}$

\section{Exploring other methods of communication}

Communication failures between OMF clinicians and pathologists may make diagnosis difficult or even impossible. Histological evaluations often have limitations leading to a descriptive diagnosis, which requires clinicopathological correlation. To avoid mistreatment, it is important to explore ways other than the report to improve the interaction, and thus improve patient care and safety. ${ }^{2,5}$ Various strategies have been suggested to maximize cross-disciplinary communication, such as interdepartmental or clinicopathological conferences. Furthermore, it is essential to remember simple strategies, such as phone calls, text messaging, e-mails, and face-to-face online interaction, whilst ensuring patient confidentiality. These methods are simple and reliable ways of clarifying unclear issues, promoting a trusting relationship between professionals, and aiding clinically relevant diagnoses ${ }^{2}$. Some diagnoses, such as those for oncological or systemic diseases, may require discussion at a multidisciplinary team meeting to ensure a holistic patient-centered view, and optimal patient care. In such cases, communication goes beyond the clinicians and pathologists, and can involve numerous other specialities. ${ }^{2,27}$

\section{Communication skills training}

Despite most health professionals recognizing communication as an essential element in the diagnostic process, there is little or no specific education in this field ${ }^{4,15}$. This scenario is even more significant in dentistry. The lack of effective communication skills is one of the major gaps in the education and training of clinicians and pathologists, and could contribute to errors in information transference and subsequently diagnostic mistakes. ${ }^{15}$ It is thus vital to create reliable communication pathways in the OMF diagnostic process, and to include specific communication training in the dental undergraduate and postgraduate curriculum, as well as clinical training. A scoping review by Ayn et al. ${ }^{28}$ described recommendations for improving communication skills in dental education. They gave an example of a general structure for this curriculum, which should be divided into two focus activities (didactic and experiential) that could be undertaken in the four years until graduation. Communication skills training should include four themes: a) student satisfaction and the perceived importance/benefit of communication skills training, b) the role of instructors, c) importance of accounting for diversity in training, and d) training structure considerations. ${ }^{28}$

Clinicians and pathologists must bear in mind the basic concepts of diagnostic communication, including personal identification (self-identification by name, position and department), patient and procedure identification, relevant surgical findings, and lesion information (oral sites, main clinical finding and detailed descriptions). Since the clinicianpathologist interplay is a joint requirement, improving communication skills needs to be discussed and 
developed mutually. Understanding the basic concepts of clinical and pathological routine in order to create empathy regarding the challenges and needs of each area often generates a fruitful team environment ${ }^{29,30}$. Communication training programs can serve to recognize communication errors and the frequency of miscommunications ${ }^{15}$, allowing participants to practice improvement strategies to reduce these flaws, and increase patient safety in the OMF diagnostic process.

\section{Patient-centered care}

One of the key concepts of the diagnostic process is patient-centered care, which is defined as "respectful of and responsive to individual patient preferences, needs, and values and ensuring that patient values guide all clinical decisions". ${ }^{31}$ Whereas patientcentered care focuses mainly on the patient's disease, person-centered care considers the patient as a person, and considers their families at the center of decisions ${ }^{31}$. The diagnostic process and patientcentered care are usually seen as separate tasks, but are synergistic. ${ }^{32}$ Pathologists must bear in mind that each piece of tissue is linked to a person who is anxiously waiting for an explanation of their health condition. For this reason, the diagnostic process must be not only patient-centered, but also person-centered, as this promotes the emotional and physical comfort of the patients. Turnaround times (TAT) are a critical issue in this context, and it is recommended that they are as short as possible. Some cases might require a considerably longer TAT, however, due to auxiliary diagnostic techniques. When this happens, the pathologists should ideally provide a provisional report, or interact verbally with the requesting clinician to keep them informed. ${ }^{1,33,34}$

Considering the absence of relevant publications on communication in the context of diagnosing
OMF pathologies, there is a dire need to develop studies that systematically evaluate this subject and identify related challenges and solutions. In our opinion, future research studies should be designed to clarify the following issues: a) the effect of the lack of clinical information on the final histopathological diagnosis; b) the effect of digital systems on gathering clinical information and the delivery of diagnosis; and c) clinician and pathologist perspectives on patient-centered care.

\section{Conclusions}

Achieving high-quality communication between clinicians and pathologists in OMF diagnosis is not simple, and involves a complex and multifaceted process. Strategies for improving communication include well-established clinician-pathologist interplay, well-formatted and thorough reports, exploring other forms of communication and training in communication skills. Finally, it is important to emphasize that a long-term relationship between a clinician and OMF pathologist, based on mutual respect, empathy, dialogue, and concern for patient well-being, is fundamental to ensuring optimal patient outcomes.

\section{Acknowledgements}

This study was supported in part by the Coordenação de Aperfeiçoamento de Pessoal de Nível Superior - Brasil (CAPES) - Finance Code 001 and the Brazilian National Council for Scientific and Technological Development - Brazil (CNPq) - 141096/2020-9. Pablo A. Vargas, Marcio A. Lopes, and Alan R. Santos-Silva are research fellows funded by CNPq. Maria Eduarda Pérez-de-Oliveira holds a PhD scholarship from the São Paulo State Research Foundation (FAPESP 2019/26676-7).

\section{References}

1. Lehr HA, Bosman FT. Communication skills in diagnostic pathology. Virchows Arch. 2016 Jan;468(1):61-7. https://doi.org/10.1007/s00428-015-1848-y

2. Suleiman DE; Pathologist-clinician collaboration. a marriage of necessity toward improving the quality of patient care. Ann Niger Med. 2015;9(1):1-3. https://doi.org/10.4103/0331-3131.163325 
Pérez-de-Oliveira ME, Heerden W, Motta ACF, Rodrigues-Fernandes CI, Romañach MJ, Agostini M, et al.

3. Troxel DB. Medicolegal aspects of error in pathology. Arch Pathol Lab Med. 2006 May;130(5):617-9. https://doi.org/10.5858/2006-130-617-MAOEIP

4. Powsner SM, Costa J, Homer RJ. Clinicians are from Mars and pathologists are from Venus. Arch Pathol Lab Med. 2000 Jul;124(7):1040-6. https://doi.org/10.5858/2000-124-1040-CAFMAP

5. Nakhleh RE. Quality in surgical pathology communication and reporting. Arch Pathol Lab Med. 2011 Nov;135(11):1394-7. https://doi.org/10.5858/arpa.2011-0192-RA

6. Nakhleh RE, Gephardt G, Zarbo RJ. Necessity of clinical information in surgical pathology. Arch Pathol Lab Med. 1999 Jul;123(7):615-9. https://doi.org/10.5858/1999-123-0615-NOCIIS

7. Nutt L, Zemlin AE, Erasmus RT. Incomplete laboratory request forms: the extent and impact on critical results at a tertiary hospital in South Africa. Ann Clin Biochem. 2008 Sep;45(Pt 5):463-6. https://doi.org/10.1258/acb.2008.007252

8. Nakhleh RE, Zarbo RJ. Amended reports in surgical pathology and implications for diagnostic error detection and avoidance: a College of American Pathologists Q-probes study of 1,667,547 accessioned cases in 359 laboratories. Arch Pathol Lab Med. 1998 Apr;122(4):303-9.

9. Speight PM, Khurram SA, Kujan O. Oral potentially malignant disorders: risk of progression to malignancy. Oral Surg Oral Med Oral Pathol Oral Radiol. 2018 Jun;125(6):612-27. https://doi.org/10.1016/i.0000.2017.12.011

10. Stojanov IJ, Woo SB. AAOM clinical practice statement subject: leukoplakia. Oral Surg Oral Med Oral Pathol Oral Radiol. 2018;26(4):331-4. https://doi.org/10.1016/j.0000.2018.06.006

11. Al-Hashimi I, Schifter M, Lockhart PB, et al. Oral lichen planus and oral lichenoid lesions: diagnostic and therapeutic considerations. Oral Surg Oral Med Oral Pathol Oral Radiol Endod. 2007;103 Suppl:S25.e1-S25.e12. https://doi.org/10.1016/i.tripleo.2006.11.001

12. MacDonald-Jankowski DS. Fibro-osseous lesions of the face and jaws. Clin Radiol. 2004 Jan;59(1):11-25. https://doi.org/10.1016/i.crad.2003.07.003

13. Owosho AA, Xu B, Kadempour A, Yom SK, Randazzo J, Ghossein RA, et al. Metastatic solid tumors to the jaw and oral soft tissue: a retrospective clinical analysis of 44 patients from a single institution. J Craniomaxillofac Surg. 2016 Aug;44(8):1047-53. https://doi.org/10.1016/i.jcms.2016.05.013

14. Bailey J, Jennings A, Parapia L. Change of pathology request forms can reduce unwanted requests and tests. J Clin Pathol. 2005 Aug;58(8):853-5. https://doi.org/10.1136/icp.2004.023101

15. Dintzis S. Improving pathologists' communication skills. AMA J Ethics. 2016 Aug; 18(8):802-8. https://doi.org/10.1001/journalofethics.2016.18.8.medu1-1608

16. Attanoos RL, Bull AD, Douglas-Jones AG, Fligelstone LJ, Semararo D. Phraseology in pathology reports: a comparative study of interpretation among pathologists and surgeons. J Clin Pathol. 1996 Jan;49(1):79-81. https://doi.org/10.1136/icp.49.1.79

17. Atchyuta M, Renuka IV, Latha PP. Comparative study on the interpretation of phraseology used in histopathology reports between senders and receivers. IP Archives of Cytology and Histopathology Research. 2018;3(3):140-3.

18. Goldsmith JD, Siegal GP, Suster S, Wheeler TM, Brown RW. Reporting guidelines for clinical laboratory reports in surgical pathology. Arch Pathol Lab Med. 2008 Oct;132(10):1608-16. https://doi.org/10.5858/2008-132-1608-RGFCLR

19. Piva E, Plebani M. Interpretative reports and critical values. Clin Chim Acta. 2009 Jun;404(1):52-8. https://doi.org/10.1016/i.cca.2009.03.028

20. Manion E, Cohen MB, Weydert J. Mandatory second opinion in surgical pathology referral material: clinical consequences of major disagreements. Am J Surg Pathol. 2008 May;32(5):732-7. https://doi.org/10.1097/PAS.0b013e31815a04f5

21. Lindley SW, Gillies EM, Hassell LA. Communicating diagnostic uncertainty in surgical pathology reports: disparities between sender and receiver. Pathol Res Pract. 2014 Oct;210(10):628-33. https://doi.org/10.1016/i.prp.2014.04.006

22. Galloway M, Taiyeb T. The interpretation of phrases used to describe uncertainty in pathology reports. Pathol Res Int. 2011;2011:656079. https://doi.org/10.4061/2011/656079

23. Bracamonte E, Gibson BA, Klein R, Krupinski EA, Weinstein RS. Communicating uncertainty in surgical pathology reports: a survey of staff physicians and residents at an academic medical center. Acad Pathol. 2016 Jul;3:2374289516659079. https://doi.org/10.1177/2374289516659079

24. Valenstein PN. Formatting pathology reports: applying four design principles to improve communication and patient safety. Arch Pathol Lab Med. 2008 Jan;132(1):84-94. https://doi.org/10.5858/2008-132-84-FPRAFD

25. Branston LK, Greening S, Newcombe RG, Daoud R, Abraham JM, Wood F, et al. The implementation of guidelines and computerised forms improves the completeness of cancer pathology reporting. The CROPS project: a randomised controlled trial in pathology. Eur J Cancer. 2002 Apr;38(6):764-72. https://doi.org/10.1016/S0959-8049(01)00258-1

26. Haugland HK, Casati B, Dørum LM, Bjugn R. Template reporting matters - a nationwide study on histopathology reporting on colorectal carcinoma resections. Hum Pathol. 2011 Jan;42(1):36-40. https://doi.org/10.1016/i.humpath.2010.06.009

27. Ruhstaller T, Roe H, Thürlimann B, Nicoll JJ. The multidisciplinary meeting: an indispensable aid to communication between different specialities. Eur J Cancer. 2006 Oct;42(15):2459-62. https://doi.org/10.1016/i.ejca.2006.03.034 
The need for communication between clinicians and pathologists in the context of oral and maxillofacial diseases

28. Ayn C, Robinson L, Nason A, Lovas J. Determining recommendations for improvement of communication skills training in dental education: a scoping review. J Dent Educ. 2017 Apr;81(4):479-88. https://doi.org/10.21815/JDE.016.003

29. Prystowsky MB. The people have spoken: are pathologists listening? Arch Pathol Lab Med. 2017 Feb;141(2):220-1. https://doi.org/10.5858/arpa.2015-0429-ED

30. Odell EW, Farthing PM, High A, Potts J, Soames J, Thakker N, et al. British Society for Oral and Maxillofacial Pathology, UK: minimum curriculum in oral pathology. Eur J Dent Educ. 2004 Nov;8(4):177-84. https://doi.org/10.1111/i.1600-0579.2004.00350.x

31. Walji MF, Karimbux NY, Spielman Al. Person-centred care: opportunities and challenges for academic dental institutions and programs. J Dent Educ. 2017 Nov;81(11):1265-72. https://doi.org/10.21815/JDE.017.084

32. Donner-Banzhoff N. Solving the diagnostic challenge: a patient-centred approach. Ann Fam Med. 2018 Jul;16(4):353-8. https://doi.org/10.1370/afm.2264

33. Patel S, Smith JB, Kurbatova E, Guarner J. Factors that impact turnaround time of surgical pathology specimens in an academic institution. Hum Pathol. 2012 Sep;43(9):1501-5. https://doi.org/10.1016/i.humpath.2011.11.010

34. Volmar KE, Idowu MO, Sovers RJ, Karcher DS, Nakhleh RE. Turnaround time for large or complex specimens in surgical pathology: a College of American Pathologists Q-Probes study of 56 institutions. Arch Pathol Lab Med. 2015 Feb;139(2):171-7. https://doi.org/10.5858/arpa.2013-0671-CP 